\title{
Is the Proportion of College Workers in "Non-College" Jobs Increasing?
}

\author{
Peter Gottschalk and Michael Hansen ${ }^{1}$
}

July 2001

\begin{abstract}
This paper explores the claim that college-educated workers are increasingly likely to be in "non-college" occupations. We provide a conceptual framework that gives analytical content to the previously vague distinction between college and noncollege jobs. We show that, when there is heterogeneity in preferences, equally productive college workers can be in college and non-college jobs. This framework is also used to show that skill-biased technological change will lead to a decline in the proportion of college workers in non-college jobs. This prediction is supported by the data.
\end{abstract}

\footnotetext{
${ }^{1}$ Gottschalk is Professor of Economics at Boston College, Chestnut Hill, MA 02467 and Hansen is a Research Analyst at The CNA Corporation, 4825 Mark Center Drive, Alexandria, VA 22311. This research was supported by a grant from the Russell Sage Foundation. We thank participants at the Institute for Research on Poverty Summer Workshop for useful comments and the editor for suggestions that resulted in a much improved paper.
} 


\section{Introduction}

It is well accepted that college graduates fared well in the 1980s, both in absolute terms and relative to high school graduates. ${ }^{2}$ Demand for college workers increased due to a number of fortuitous factors including skill-biased technological change and an increase in international trade. Meanwhile, the real wages of high school educated workers declined, leading to a substantial increase in the college premium.

In contrast to this literature is the claim that an increasing proportion of college-educated workers were faring sufficiently poorly that they were having to take "non-college" jobs. The possibility that college workers were being displaced into jobs formerly held by non-college workers has been largely ignored in the economics literature. This lack of attention undoubtedly reflects the subjective nature of classifications of occupations as "college" or "non-college" jobs used in previous studies. For example, Amirault (1990) and Hecker (1992) base their classifications on the respondent's perception of the education requirement for each occupation. Rumberger (1981), Howell and Wolff (1991), and Mishel and Teixeira (1991) use skill requirements based on the Dictionary of Occupational Titles.

A second reason for the disjunction between this literature and the better known literature on growing wage inequality is that it implies that college workers were taking jobs with declining real wages. However, since the dispersion of the wage distribution was increasing both for college and noncollege workers, it is possible that wages at the bottom of the college distribution were falling sufficiently fast to warrant a college-educated worker accepting a job from the top of the distribution of wages offered to non-college graduates.

\footnotetext{
${ }^{2}$ For example, see Katz and Murphy (1992), Levy and Murnane (1992), and Gottschalk (1997).
} 
We take a fresh look at this issue by providing a rigorous definition of "non-college" jobs and examining recent data for young college graduates. Section 1 provides an analytical framework that we use to motivate a definition of "non-college" jobs based on standard economic concepts. This framework shows that equally productive workers can be in college and non-college jobs as long as there is heterogeneity in preferences. We also use this framework to derive a testable relationship between skill-biased technological change and changes in the proportion of college graduates in "noncollege" jobs. Section 2 describes our data, while section 3 explains how we implement our definition of "non-college" jobs. In section 4 we present our results; section 5 provides a summary of our findings.

Consistent with our analytical framework, we find that the proportion of college-educated workers in "non-college" occupations declined from the mid-1980s to the mid-1990s. These statistically significant results are robust to a large number of specification checks, and stand in stark contrast to those in previous studies. We find no evidence to support the notion that an increasing proportion of over-qualified college graduates were being forced to accept "non-college" jobs.

\section{Analytical Framework}

In this section, we provide a simple analytical framework that motivates our empirical analysis. This framework is used to give economic content to the concept of a "non-college" job and to show how changes in labor demand affect the allocation of workers in these jobs. Specifically, we show how skill-biased technological change affects the proportion of college workers in "non-college" jobs.

\section{Demand}

Consider the following two-sector model in which a final or intermediate output is produced using both college and non-college workers. For example, college and non-college workers may be 
inputs into an occupation-specific intermediate output. The following production functions characterize the technologies in these two sectors:

$\mathrm{Q}_{1}=\mathrm{F}_{1}\left(\mathrm{~K}_{1}, \alpha_{1 \mathrm{c}} \mathrm{L}_{1 \mathrm{c}}+\alpha_{1 \mathrm{n}} \mathrm{L}_{1 \mathrm{n}}\right)$

$\mathrm{Q}_{2}=\mathrm{F}_{2}\left(\mathrm{~K}_{2}, \alpha_{2 \mathrm{c}} \mathrm{L}_{2 \mathrm{c}}+\alpha_{2 \mathrm{n}} \mathrm{L}_{2 \mathrm{n}}\right)$

where $L_{j c}$ and $L_{j n}$ are the number of college and non-college graduates, respectively, who work in sector $\mathrm{j}(\mathrm{j}=1,2)$.

$\alpha_{j c}$ and $\alpha_{j n}$ are the number of efficiency units embodied in college and non-college workers in each sector. Thus, we assume that, while college workers may embody greater efficiency units (i.e., $\alpha_{\mathrm{jc}}$ $>\alpha_{j n}$ ), the two types of labor are perfect substitutes. Sector 2 is the "non-college" sector, in the sense that $\left(\alpha_{2 \mathrm{c}} / \alpha_{2 \mathrm{n}}\right)<\left(\alpha_{1 \mathrm{c}} / \alpha_{1 \mathrm{n}}\right)$. This implies that productivity of college graduates is more similar to that of non-college graduates in sector 2 than in sector 1.

Firms are price takers and choose $\mathrm{L}_{\mathrm{c}}$ and $\mathrm{L}_{\mathrm{jn}}$ to maximize $\left[\mathrm{P}_{\mathrm{j}} \mathrm{Q}_{\mathrm{j}}-\mathrm{W}_{\mathrm{jc}} \mathrm{L}_{\mathrm{jc}}-\mathrm{W}_{\mathrm{jn}} \mathrm{L}_{\mathrm{jn}}\right]$. The first order conditions yield the following demand equations for sector $j(j=1,2)$ :

$\mathrm{W}_{\mathrm{jc}}=\alpha_{\mathrm{jc}} \mathrm{F}_{\mathrm{j}}{ }^{\prime}$

$\mathrm{W}_{\mathrm{jn}}=\alpha_{\mathrm{jn}} \mathrm{F}_{\mathrm{j}}^{\prime}$

These demand equations imply that the college premium within a sector is $\left(\mathrm{W}_{\mathrm{jc}} / \mathrm{W}_{\mathrm{jn}}\right)=\left(\alpha_{\mathrm{jc}} / \alpha_{\mathrm{jn}}\right)$

Given our assumption on $\left(\alpha_{\mathrm{j} d} / \alpha_{\mathrm{jn}}\right)$, the college premium, $\frac{W_{j c}}{W_{j n}}$, is smaller in sector 2 than in sector 1 .

This simple framework motivates our definition of "college" and "non-college" jobs. We define a non-college job as one that offers a low college premium. In our simple model, non-college jobs are those in sector 2 . 


\section{Supply}

All college and non-college graduates work in either sector 1 or sector 2 . The number of college graduates, $\mathrm{L}_{c}$, and non-college graduates, $\mathrm{L}_{\mathrm{n}}$, is exogenous. Workers choose whether to work in sector 1 or sector 2 based on their heterogeneous preferences and the relative wages available to them across sectors:

$$
\begin{aligned}
& \ln \left(L_{1 c}\right)=\lambda_{c}+\beta_{c} \ln \left(W_{1 c} / W_{2 c}\right) \\
& \ln \left(L_{1 n}\right)=\lambda_{n}+\beta_{n} \ln \left(W_{1 n} / W_{2 n}\right)
\end{aligned}
$$

where $\lambda_{c}$ and $\lambda_{n}>0$, and $\beta_{c}$ and $\beta_{n}>0$. As the wage in the college sector rises, this draws in the marginal worker, whose preferences made him indifferent between working in either sector.

For notational convenience, define the proportion of college graduates in sectors 1 and 2 as

$$
\begin{aligned}
& \left(1-\pi_{c}\right) \equiv L_{1 c} / L_{c} \\
& \pi_{c} \equiv L_{2 c} / L_{c} .
\end{aligned}
$$

Likewise, $\left(1-\pi_{n}\right)$ and $\pi_{n}$ are the proportion of non-college workers in sectors 1 and 2 , respectively.

\section{Equilibrium}

The demand for college and non-college workers in each sector depends on the sector-specific college premium that employers pay college workers over non-college workers (equations 3 and 4), while the supply of workers across sectors depends on their relative wages across the two sectors (equations 6 and 7). Together, these four equations determine the allocation of the two types of workers across the two sectors. 
Note that, in equilibrium, some college workers voluntarily choose to be in sector 2 , the noncollege sector (i.e., $\pi_{c}>0$ ). Those college graduates with a relative preference for the non-college sector are willing to be in that sector, given the relative wages across sectors. As relative wages change across sectors, so does the supply of college graduates across sectors. In this sense, the fact that some college workers are in non-college jobs does not signal a misallocation of resources or an involuntary assignment across sectors. Wages adjust to induce college workers to reallocate across sectors.

This simple model can be used to analyze the impact of skill-biased technological change in sector 1 in reallocating college workers across sectors. Skill-biased technological change in sector 1 is parameterized as an increase in $\alpha_{1 c}$. It can be shown that, if sector 2 employs a greater proportion of the non-college workers than of the college workers (i.e., $\left.\pi_{\mathrm{n}}>\pi_{\mathrm{c}}\right)^{3}$, then $\frac{\partial \pi_{c}}{\partial \alpha_{1}}<0 .{ }^{4}$ In other words, as the productivity of college graduates in sector 1 rises, the proportion of college graduates employed in sector 2 falls. Intuitively, the increase in the relative productivity of college workers in sector 1 raises their relative wages, which, in turn, induces college workers in non-college jobs (sector 2) to enter this higher paying sector. This two sector framework can be easily expanded to k sectors, in which some subset experience skill-biased technological change. Again, there will be an outflow of college workers from the sectors that do not experience the technological change. If sectors are defined as sectors with a

\footnotetext{
${ }^{3}$ Taking our labor supply functions (equations 6 and 7) and the fact that, in equilibrium, the college premium in each sector is given by technological parameters (equation 5), the relationship between $\pi_{\mathrm{c}}$ and $\pi_{\mathrm{n}}$ is $\beta_{\mathrm{n}} \ln \left(1-\pi_{\mathrm{c}}\right)-\beta_{\mathrm{c}} \ln \left(1-\pi_{\mathrm{n}}\right)=\beta_{\mathrm{c}} \ln \left(\mathrm{L}_{\mathrm{n}}\right)-\beta_{\mathrm{n}} \ln \left(\mathrm{L}_{\mathrm{c}}\right)+\beta_{\mathrm{n}} \lambda_{\mathrm{c}}-\beta_{\mathrm{c}} \lambda_{\mathrm{n}}+\beta_{\mathrm{c}} \beta_{\mathrm{n}} \ln \left(\alpha^{*}\right)$, where $\alpha^{*} \equiv\left(\alpha_{1 \mathrm{c}} / \alpha_{1 \mathrm{n}}\right) /\left(\alpha_{2 \mathrm{c}} / \alpha_{2 \mathrm{n}}\right)>1$. We require that $0<\pi_{\mathrm{c}}<\pi_{\mathrm{n}}<1$, which is satisfied by a large set of parameter values. For example, if $\ln \left(L_{\mathrm{n}}\right)=\ln \left(\mathrm{L}_{\mathrm{c}}\right)$ and $\beta_{\mathrm{c}}=\beta_{\mathrm{n}}$, a sufficient condition for $\pi_{\mathrm{c}}<\pi_{\mathrm{n}}$ is that $\lambda_{\mathrm{c}}>\lambda_{\mathrm{n}}$. In other words, a greater proportion of college graduates will be in sector 1 if the supply curve of college graduates in sector 1 is everywhere higher than that of non-college graduates.

${ }^{4}$ Proof is available from the authors upon request.
} 
college premium below a fixed threshold, then some non-college sectors will become college sectors as a result of a rising premium in those sectors.

In summary, the conceptual model that we have developed in this section points to the importance of two sets of relative prices in determining the equilibrium distribution of workers across sectors and the college premium in each sector. Firms must be willing to hire the equilibrium mix of workers based on the relative price of college and non-college workers, and workers must be willing to work in those sectors based on the relative wages they could receive in alternative sectors. We have shown that college workers employed in sectors with low college premiums (i.e., the non-college sector) can be an equilibrium outcome. Relative wages adjust across sectors to allocate college workers to both sectors. We have shown that skill-biased technological change is predicted to reduce the proportion of college workers in these sectors. The empirical work presented in the following sections examines whether this prediction is consistent with the data.

\section{Data}

We make use of the Current Population Survey (CPS) to estimate the proportion of college workers in non-college occupations (i.e., those with returns to college below a fixed threshold). Our sample is taken from the 1983-1996 CPS, which provide earnings for 1982-1995. This time period allows us to examine the employment of college graduates in college and non-college jobs (defined in terms of the returns to college in 3 digit occupations) during a time when the college premium was rising. We start in 1982 in order to reduce the effects of changes in occupational classification. ${ }^{5}$

\footnotetext{
${ }^{5}$ Since 1964, the CPS has used five different occupation classification codes. Beginning with the 1983 interview, the CPS began to use the 1980 Census of Population Occupation Classification and switched to the 1990 Classification in the 1992 interview. The differences between these two classifications are relatively minor. Appendix N.7 of the
} 
Both males and females are included in our sample, which includes non-students with 12 to 17 years of education and ten years or less of (potential) labor market experience. ${ }^{6}$ The experience restriction is imposed in order to focus on the early labor market experiences of college graduates. The education cut is imposed since we focus on the premiums paid to college graduates over those with a high school degree but without a college degree. ${ }^{7}$ We include part-time and part-year workers in order to obtain sufficiently large samples when estimating college premiums at the 3 -digit level. ${ }^{8}$ Individuals who are self-employed on their main job, report working zero weeks, or working more than 98 hours per week during the previous year are excluded. Our earnings measure is average weekly wages, expressed in 1994 dollars (using the chain-weighted Personal Consumption Expenditures deflator, PCE). ${ }^{9}$

In order to verify that our sample gives results consistent with those found in the inequality literature, Figure 1 shows the college premium for our sample of recent labor market entrants. This premium is measured by the college differential (the difference in log earnings between a college graduate and a non-college graduate) in a log weekly wage regression, estimated separately for each year. ${ }^{10}$ Even though our sample includes non-FT/FY workers, the trend in the college premium is

Unicon documentation contains a list of the differences between the 1980 and 1990 classifications. Also, see Appendix N.5 and Appendix N.6, respectively, for the complete 1980 and 1990 classifications.

${ }^{6}$ Potential labor market experience is defined as Age - Years of Education - 6. Beginning with the 1992 interview, the CPS switched from reporting years of education to reporting educational attainment. For the latter part of our sample period, individuals are included if they hold a high school diploma or equivalent, have attended some college, or hold an associate's or bachelor's degree. For discussion of the change in educational coding see Jaeger (1997).

${ }^{7}$ Jaeger (1997) concludes that a person with 17 years of education should be included as a college graduate (someone whose highest degree is a BA) since a large number of students are taking five years to obtain a BA. Note that our college premium is the log differential of a college graduate (i.e., 16 or 17 years of education) over a person with at least a high school degree (i.e., 12-15 years of education).

${ }^{8} \mathrm{We}$ control for full-time status in our estimates of the college premiums.

${ }^{9}$ We also performed our analysis using annual earnings; the results are qualitatively similar to those using average weekly earnings.

${ }^{10}$ The sample for each regression consists of individuals with 10 years or less of experience. Each regression includes a dummy variable for college, dummy variables for Hispanics and Blacks (non-Hispanic), a dummy variable 
strikingly similar to those presented elsewhere in the literature (e.g., Katz and Murphy, 1992, Figure 1 and Gottschalk, 1997, Figure 5). ${ }^{11}$

\section{Classification of Occupations}

Consistent with the analytical framework presented earlier, our definition of a "non-college" occupation focuses explicitly on the premium paid to college-educated workers. ${ }^{12}$ An occupation with a large college premium signals that college workers have skills that are valued by employers in that occupation. On the other hand, employers in some jobs hire both college-educated workers and workers with less education, but do not offer a premium for college-educated labor (for example, cashiers). ${ }^{13}$

Our estimates of occupation-specific college premiums are obtained from occupation-specific $\log$ wage regressions. These premiums are estimated in each year for each 3-digit occupation that has a sufficient number of college and non-college workers. ${ }^{14}$ In order to obtain sufficiently large samples, we merge data for years $\mathrm{t}-1, \mathrm{t}$, and $\mathrm{t}+1$ when estimating returns in $\mathrm{t}^{15}$ For example, a college premium in a specific 3-digit occupation for 1983 uses data from 1982-1984. ${ }^{16}$

for females, a dummy variable for full-time workers, and a quadratic in (potential) experience. The CPS defines "fulltime workers" as those who work $35+$ hours per week.

${ }^{11}$ The patterns are similar whether or not we include persons with 13 to 15 years of education in the denominator.

${ }^{12}$ Occupations where employers do not hire any non-college workers (for example, in hiring physicians) are also classified as college jobs. This is a special case of our definition, since it implies that employers are not willing to hire non-college workers at any discount.

${ }^{13}$ Tyler, Murnane, and Levy (1995) observe that many occupations typically classified as non-college jobs in the previous literature actually pay a premium to college graduates.

${ }^{14}$ The premium paid to college graduates within a occupation can change over time.

${ }^{15}$ In addition to the independent variables noted earlier, each log earnings regression also includes dummy variables for years $\mathrm{t}-1$ and $\mathrm{t}+1$.

${ }^{16}$ As a result, we are able to estimate occupation-specific college premiums for each year from 1983 to 1994 . We are not able to estimate college premiums for an occupation in 1982 and 1995 (the first and last year in our sample), since data for 1981 and 1996 are not part of our sample. 
While our definition of a college job has the conceptual advantage of being based on market signals (i.e., employers' willingness to pay a premium for college-educated workers) rather than on subjective judgments, it puts strong requirements on the data. Ideally, we would like to estimate college premiums for narrowly-defined occupations. This would allow us to compare the wages of college and non-college workers in the same job (e.g., aerobics nstructors). This is not always possible, either because 3-digit occupations are already aggregations or because we must further aggregate in order to obtain a sufficient sample size. ${ }^{17}$

An occupation-specific college premium is estimated for all occupations with at least 50 college and 50 non-college workers. ${ }^{18}$ Occupations with less than 50 college or 50 non-college workers are pooled with other occupations at the next higher level of aggregation in the 1980 Census Classification. For example, "Financial managers" are included in their own occupation, while "Legislators", "Chief executives \& general administrators, public administration", and "Administrators and officials, public administration" are pooled into the occupational category "Public Administration". Appendix 1 provides a list of the occupations that were merged..$^{19}$

In order to avoid combining occupations, such as lawyers, that require a college degree with other occupations that include a mixture of college and non-college graduates, we classify occupations with more than 90 percent college graduates as "college" jobs. These occupations ("Architects", "Biological and life scientists", "Health Diagnosing Practitioners", "Speech therapists", "Teachers,

\footnotetext{
${ }^{17}$ The 3-digit occupation classification system used by the Census already reflects different degrees of aggregation by occupation. For example, "Marketing Managers", “Advertising Managers", and "Public Relations Managers" are considered "Managers, marketing, advertising, and public relations" by the Census, while "Metallurgical Engineers" and "Mining Engineers" are treated as separate occupational categories.

${ }^{18}$ We use the 1982-1984 CPS data to determine which occupations to aggregate. This aggregation is maintained in all other years so that the definitions of occupational cells do not change over time. Changes over time in the college premium for the cell, therefore, do not reflect changes in the occupations being aggregated.

${ }^{19}$ In our empirical work, we explore whether this aggregation is driving our results.
} 
elementary school", "Teachers, secondary school", "Teachers, special education", "Lawyers", and "Judges") include 12.5 percent of college graduates. ${ }^{20}$ This approach leaves us with 82 occupational categories for which a college premium can be estimated in at least one year. ${ }^{21}$ These represent 29 occupations at the 3 -digit level, which include 34 percent of college graduates, and 53 aggregated categories that include the remaining 53.5 percent of college graduates. In all cases these are more detailed than the standard, 2-digit classification.

"Non-college" jobs are defined as those with a college premium below a fixed threshold. We initially set the threshold at .10, which is a quarter as high as the lowest overall college premium in Katz and Murphy (1992, Figure 1). ${ }^{22}$ To test for robustness, we use different thresholds and find that the choice of threshold does not affect our results.

Table 1 contains a listing of occupations, as well as the estimated college premium, percent of college graduates, and average weekly wages of college graduates in these occupations in both 1983 and 1994. Occupations are ranked by the estimated college premium in 1983. The first column shows that most occupations commonly viewed as "non-college" jobs do indeed offer low premiums to college graduates. For example, carpenters, cashiers, cooks, office clerks, and financial records processors all have low premiums. Other occupations that might be classified as "non-college" in a

\footnotetext{
${ }^{20}$ In determining the proportion of workers within an occupation with at least a BA, postgraduates (and those with 18 years of education in the 1983-1991 CPS) are included in the sample. Once these calculations have been made, however, postgraduates are excluded from the estimation of college premiums.

${ }^{21}$ If, in subsequent years, an occupation does not have at least 50 college and 50 non-college workers, a premium is not estimated for that occupation in that year.

${ }^{22}$ As an alternate measure, we also calculate the probability that each occupation-specific college premium is less than 10 percent. College graduates are then assigned the probability that the occupation in which they are employed offers a premium less than 10 percent, and the aggregate probability is given by the average of these probabilities. This approach has the advantage of incorporating information on both the point estimate and the precision of the estimate of the college premium. This mitigates the possibility that an occupation is misclassified due to a noisy estimate, and reduces the chance that an occupation switches from "non-college" to "college" status from one year to the next due to a statistically insignificant change in the estimated premium. We obtain similar results to those reported in this paper when we use this alternate measure.
} 
subjective ranking, however, turn out to pay substantially more to college-educated workers than to workers without a college degree (for example, child care workers). Furthermore, our method allows us to classify occupations, such as purchasing agents, that cannot be readily classified using the subjective ranking found in the previous literature. The second column displays the percent of all college graduates employed in each occupation in 1983. 10.7 percent of all college graduates in 1983 worked in occupations with a college premium less than .10 .

We also calculated the average weekly wages of college graduates in each occupation (column 3), and find only a weak relationship between the college premium and the level of wages offered to college graduates within an occupation. While the correlation between the college premium and average college wage is positive (.33), there are occupations that offer relatively low premiums and high wages (for example, carpenters), as well as occupations that offer high premiums and relatively low wages (for example, child care workers). This is consistent with the equilibrium described in our empirical framework; the supply of college graduates in a given occupation depends on the relative wages offered to college graduates, as well as on individual preferences for different occupations.

Columns 4, 5 and 6 display, for each occupation, the estimated college premium, percent of college graduates employed, and average weekly wages of college graduates in the occupation in 1994. A comparison of columns 1 and 4, as well as of columns 2 and 5 and of columns 3 and 6, suggests that there were significant changes within some occupations over this time period, both in the premium offered to college graduates, the percent of graduates in these occupations, and the average wages paid to these graduates. This comparison previews our empirical findings presented in the next section, where we examine these changes over time in more detail. 
In order to see whether there is any systematic relationship between the level of aggregation and the estimated college premiums, we indicate aggregated occupations in Table 1 by an asterisk. Aggregated occupations are spread throughout the distribution, though they have a somewhat higher mean premium (.27 versus .22$).^{23}$ As an additional check on the effect of our aggregation of some 3digit occupations, we also later discuss results based on occupations that did not require aggregation.

\section{Findings}

Figure 2 displays kernel density estimates of college premiums in 1983 and 1994 for our sample of recent college graduates (i.e., those with ten years or less of potential labor market experience). ${ }^{24}$ This figure illustrates two important points. First, college graduates are distributed across occupations that offer widely different premiums. For example, while the mean premium in 1994 is .33, about five percent of college graduates were in occupations offering a college premium of .10 or less, while the top ten percent had premiums above 45 percent. Furthermore, it is clear from Figure 2 that there is a substantially higher concentration of college graduates in occupations offering high premiums in 1994 than there was in 1983. There are also fewer college graduates employed in occupations that offer a premium less than 10 percent. This "shift to the right" of the density function is consistent with the increase in the mean college premium displayed in Figure 1.

Table 2 presents logit estimates of the probability that a college graduate is employed in a noncollege job (i.e., one with a college premium less than .1). Independent variables include gender, race, and annual unemployment rates. ${ }^{25}$ A quadratic time trend is included to test whether the proportion has

\footnotetext{
${ }^{23}$ This difference is statistically different from zero.

${ }^{24}$ Each individual is assigned the college premium in their occupation.

${ }^{25}$ We use the civilian unemployment rate by gender and by race from the 1999 Economic Report to the President (Table B-43, p. 377).
} 
declined as predicted by our analytical model. The model estimated in table 2 can be thought of as a reduced-form model, with the coefficients reflecting both the relative supply preferences of college and non-college workers, as well as differences in relative productivity.

The estimated coefficients and standard errors for each variable are shown in column 1 . Marginal effects are shown in column $2 .{ }^{26}$ The coefficients on the quadratic time trend, jointly significant at the 1 percent level, imply that the proportion of college graduates in non-college jobs declined significantly from 1983 to 1994 , and that this decline slowed over time. Figure 3 shows the predicted values from Table $2 .^{27}$ This figure shows that there was a sharp decline in the probability that a college graduate was employed in an occupation with a premium less than .1 throughout the 1980 s, with a slowdown in this decline during the 1990s.

These changes in the proportion of college graduates in non-college jobs are consistent with the widely accepted skill-biased technological change that took place over the same period. As predicted by our analytical framework, skill-biased technological change should lead to an increase in the college premium during the 1980s and a reduction in the proportion of college graduates in non-college occupations. As the growth in the college premium slowed in the 1990s, the proportion of graduates in non-college jobs stopped declining as rapidly as during the 1980s.

If previously used definitions of non-college jobs would have led to the same decline, our definition might be conceptually preferable but have little practical importance. To address this issue, we calculate the probability that a college-educated worker was in a "non-college" job using the

\footnotetext{
${ }^{26}$ Marginal effects are measured using the average derivative.

${ }^{27}$ Predicted values are evaluated at the sample means.
} 
classification scheme adopted by Hecker (1992), the most widely cited study. ${ }^{28}$ Table 3 presents the coefficient estimates and marginal effects from this approach. The results are striking. While our series shows a 6.6 percentage point decline from 1983 to 1994 (holding all other factors constant), Hecker's definition shows a 2.2 percentage point increase which is not statistically different from zero. ${ }^{29}$ Thus, while both definitions include such obvious occupations as carpenters and cooks as "non-college" jobs, they differ in important ways for less obvious occupations. We conclude that the choice of classification schemes is not immaterial to the debate.

Furthermore, our empirical results do not support the notion that college graduates were being forced from college into non-college jobs. Rather, our approach shows a significant trend in the opposite direction, and is consistent with the skill-biased technological change widely hypothesized to have taken place over this time period. While alternative explanations, such as changes in preferences away from non-college jobs, cannot be ruled out, our explanation is consistent with broadly recognized changes in labor markets.

\section{Sensitivity of Results}

We performed several specification checks, in order to see whether our results are robust to changes in sample and definitions. In order to assess whether our results are affected by our choice of .1 as the threshold premium, we re-estimated the logit model using thresholds of .15 and .20 . In both

\footnotetext{
${ }^{28}$ Hecker (1992) classifies "Executive, Administrative, and Managerial”, "Professional Specialty", "Technicians", "Sales Representatives", and supervisors in blue-collar occupations as "college" jobs. All other occupations in "Sales", "Administrative Support", "Service”, "Farming, Forestry, and Fishing", "Precision Production, Craft, and Repair", and "Operators, Fabricators, and Laborers" are considered "high school" jobs.

${ }^{29}$ Our estimates using Hecker's definition are consistent both qualitatively with Hecker (1992), who finds little change during the 1980s, and quantitatively with the estimates for recent college graduates in Tyler, Murnane, and Levy (1995).
} 
cases, we continue to see a significant decline in the probability of employment in non-college jobs over this time period. Similarly, inclusion of non- full time/full year (non-FT/FY) workers is not driving our results. In fact, both FT/FY and non-FT/FY workers experienced significant declines over this time period.

We also replaced the quadratic in year by a set of year dummies, to see whether our conclusions are driven by the particular functional form we used. They are not. The proportion of college workers in non-college jobs declines sharply between 1984 and 1998, increases moderately through 1991, and then returns to its 1988 low by 1993.

Our inclusion of job categories that are aggregations of 3-digit occupations is also not responsible for the significant decline in the proportion of college graduates in non-college occupations. Even when we exclude these occupations from the analysis, we still find a sharp decrease over the sample period in the probability that a college-educated worker was in a 3-digit non-college occupation..$^{30}$

We also restricted our analysis to those occupations for which a college premium can be estimated in every year of our sample period. Our qualitative results are robust to this change in the choice of occupations. We conclude, then, that changes in our estimate of the probability that college graduates work in non-college jobs are not caused by changes in the mix of occupations for which college premiums are estimated.

When expanding our framework to $\mathrm{k}$ sectors, our model implies that college-educated workers will flow into jobs that experience skill-biased technological change. Since our empirical implementation uses a fixed threshold, this implies that some occupations could switch from being below to being above 
the threshold. Changes in the proportion of college graduates in jobs offering premiums below a fixed threshold, therefore, can reflect both changes in the distribution of college graduates across occupations and changes in the classification of occupations from non-college to college jobs.

To assess the relative importance of these two factors, we perform a standard decomposition of the change in the proportion of college graduates in non-college jobs. First, we calculate the proportion of college-educated workers who would have been in non-college jobs in 1994 using the 1983 classification. The difference between the actual 1983 proportion and this hypothetical 1994 proportion gives the change attributed to changes in the allocation of college workers, holding the classification constant. The impact of the change in classifications, then, is the difference between the overall change and the change attributed to the shift in the allocation of college graduates. This decomposition indicates that 22 percent of the decline in the proportion of college-educated workers in non-college jobs can be attributed to outflows from occupations initially classified as non-college. The remainder is attributed to changes in the composition of the occupations offering premiums below .10. We conclude that both factors are important.

While the analytical model we presented earlier points to the importance of both factors, previous studies have implicitly assumed that occupations did not change classifications. Therefore, when making comparisons with these studies, one might want to include only that part of the total change that is attributed to changes in the distribution of college workers across a fixed set of occupations. Our conclusions, however, are unaffected by using a fixed set of occupations. The change in our occupation-constant proportion is still significantly negative, unlike the insignificant change using Hecker's (1992) occupation-constant classification.

\footnotetext{
${ }^{30}$ College graduates in aggregated occupations are dropped from the sample used to estimate this logit model.
} 


\section{Conclusion}

We have taken seriously the claim that college-educated workers were increasingly likely to be in "non-college" jobs during the 1980s. The implied deterioration of the prospects of college workers would seem to be inconsistent with the well-known increase in the mean wages of college graduates and the decline in the mean wages of less educated workers. The relative improvement for the typical college graduate, however, need not translate into improvement for all college graduates. In fact, the increasing dispersion of wages within education groups implies that college-educated workers at the bottom of their distribution might have found offers from the top of the non-college distribution increasingly attractive.

We provide an analytical framework that puts economic content behind the diffuse notion of a "non-college" job. Employers choose the educational composition of workers on the basis of the college premium they have to pay. Workers choose occupations on the basis of their heterogeneous preferences and the education-specific wages in each occupation. In equilibrium, wages adjust to allocate workers across occupations based on their productivity and preferences.

This framework makes it clear that college workers in non-college jobs can be an equilibrium outcome, even when workers are equally productive but differ only in preferences. There need not be any rationing pushing college-educated workers into inferior outcomes. Wages adjust to allocate workers across sectors depending on changes in productivities.

Our framework leads to the prediction that skill-biased technological change will reduce the proportion of college-educated workers in non-college jobs. The predicted mechanism is simple. College-educated workers will flow out of non-college jobs as they are attracted by the increased wages in college jobs caused by the skill-biased technological change. 
We have provided evidence from the March CPS consistent with these predictions. Contrary to previous studies, we find that the proportion of college-educated workers in non-college occupations declined from the mid-1980s to the mid-1990s. These statistically significant results are robust to a large number of specification checks, and are consistent with a decline in the equilibrium allocation of college-educated workers to non-college jobs. 


\section{References}

Amirault, Thomas A. "Labor Market Trends for New College Graduates," Occupational Outlook Quarterly 34(3), Fall 1990, 10-21.

Fitzgerald, John, P. Gottschalk, and R. Moffitt. "An Analysis of Sample Attrition in Panel Data: The Michigan Panel Study of Income Dynamics," The Journal of Human Resources 33(2), Spring 1998, 251-299.

Gottschalk, Peter. "Inequality, Income Growth, and Mobility: The Basic Facts," Journal of Economic Perspectives 11(2), Spring 1997, 21-40.

Hecker, Daniel E. "Reconciling Conflicting Data on Jobs for College Graduates," Monthly Labor Review 115(7), July 1992, 3-12.

Howell, David R. and Edward N. Wolff. "Trends in the Growth and Distribution of Skills in the U.S. Workplace, 1960-1985," Industrial and Labor Relations Review 44(3), April 1991, 486502.

Jaeger, David A. "Reconciling Educational Attainment Questions in the CPS and the Census," Monthly Labor Review 120(8), August 1997, 36-40.

Katz, Lawrence F. and Kevin M. Murphy. "Changes in Relative Wages, 1963-1987: Supply and Demand Factors," Quarterly Journal of Economics 107(1), February 1992, 35-78.

Levy, Frank and Richard J. Murnane. "U.S. Earnings Levels and Earnings Inequality: A Review of Recent Trends and Proposed Explanations," Journal of Economic Literature 30, September 1992, 1333-1381.

Mishel, Lawrence and Ruy A. Teixeira. "Behind the Numbers: The Myth of the Coming Labor Shortage," The American Prospect, Fall 1991, 98-103.

Rumberger, Russell W. "The Changing Skill Requirements of Jobs in the U.S. Economy," Industrial and Labor Relations Review 34(4), July 1981, 578-590.

Tyler, John, R. J. Murnane, and F. Levy. 'Are More College Graduates Really Taking 'High School' Jobs?” Monthly Labor Review 118(12), December 1995, 18-27. 


\section{Appendix 1 \\ Correspondence Between Occupation Classification and 3-Digit Census Designation}

The following list identifies the correspondence between the occupation classification we use and the 3-

digit classification used in the 1980 Census. For the changes in code from the 1980 to 1990 Census, see Appendix

N.7 of the Unicon CPS documentation.

\section{Occupation Category}

Public Administration

Financial Managers

Managers, Marketing and Advertising

Real Estate Managers

Miscellaneous Managers and Administrators

Accountants and Auditors

Miscellaneous Financial Officers

Personnel, Training, and Labor Relations Specialists

Purchasing Agents and Buyers

Miscellaneous Management Related Occupations

Architects

Miscellaneous Professional Specialty Occupations

Engineers, Not Elsewhere Classified

Electrical and Electronic Engineers

Mathematical and Computer Scientists

Biological and Life Scientists

Health Diagnosing Occupations

Registered Nurses

Health Assessment and Treating Occupations, n.e.c.

Therapists, n.e.c.

Speech Therapists

Postsecondary Teachers

Prekindergarten and Kindergarten Teachers

Elementary School Teachers

Secondary School Teachers

Special Education Teachers

Teachers, Not Elsewhere Classified

Counselors, Librarians, Archivists, and Curators

Social Workers

Recreation and Religious Workers

Lawyers

Judges

Designers

Editors and Reporters

Writers, artists, and related workers, n.e.c.

Painters, Sculptors, and Photographers

Public Relations Specialists, Announcers, and Athletes

Clinical Laboratory Technologists and Technicians

Health Technologists and Technicians

Engineering Technologists and Technicians
1980 Census Code

3-5

7

13

16

$6,8-9,14-15,17-19$

23

25

27

28-33

$24,26,34-37$

43

$63,69-77,79,83$ 166-173

44-54, 56-59

55

64-68

78

84-89

95

96-97, 106

98-103, 105

104

113-154

155

156

157

158

159

163-165

174

175-177

178

179

185

195

183-184,186-187, 193-194

188-189

197-199

203

204-208

213-216 
$\underline{\text { Occupation Category (cont.) }}$

Drafting Occupations, Surveying and Mapping Technicians

Science Technicians

Technicians, n.e.c.

Computer Programmers

Legal Assistants

Supervisors and Proprietors, Sales Occupations

Insurance Sales Occupations

Real Estate Sales Occupations

Securities and Financial Services Sales Occupations

Sales Occupations, Advertising and Other Business Services

Sales Representatives, Commodities Except Retail

Sales Workers, Retail

Cashiers

Sales Related Occupations

Supervisors, Administrative Support Occupations

Computer Equipment Operators

Secretaries

Stenographers and Typists

Information Clerks

Records Processing Occupations, Except Financial

Financial Records Processing Occupations

Administrative Support Occupations, n.e.c.

Mail and Message Distributing Occupations

Material Recording, Scheduling, and Distributing Clerks, n.e.c.

Insurance Adjusters, Examiners, and Investigators

Miscellaneous Adjusters and Investigators

General Office Clerks

Service Occupations, n.e.c.

Child Care Workers

Protective Service Occupations, Excluding Police and Detectives

Police and Detectives

Food Preparation and Service Occupations, Excluding Waiters and Waitresses

Waiters and Waitresses

Cooks

Dental Assistants and Health Aides

Nursing Aides

Cleaning and Building Service Occupations, Excluding Household

Farm Occupations

Agricultural, Forestry, Fishing, and Hunting Occupations

Mechanics and Repairers, Vehicle and Industrial Machinery

Other Mechanics and Repairers

Construction Trades, n.e.c.

Carpenters, Electricians, and Painters

Extractive and Precision Production Occupations

Supervisors, Production Occupations

Machine Operators

Fabricators and Assemblers, Miscellaneous Production Occupations

Transportation and Material Moving Occupations

Handlers and Laborers, n.e.c.

Freight, Stock, Material Handlers, and Service Station Occupations

Armed Forces

\section{Census Code}

$217-218$

223-225

226-228, 233, 235

229

234

243

253

254

255

256-257

258-259

263-274

276

275, 277-285

303-307

308-309

313

314-315

316-323

325-336

337-344

345-353, 377-378, 383-389

354-357

359-374

375

376

379

403-405,407,456-467,469

406, 468

413-417, 425-427

418-424

433-434, 438-444

435

436-437

445-446

447

448-455

473-484

485-499

503-519

523-549

553-566,569-573,576-577,583-599

$567,575,579$

613-617, 634-699

633

703-779

783-799

803-859

$863-874,885-889$

875-883

905 
Figure 1

College Premium for

Young Labor Market Entrants

1982-1995 -- March CPS

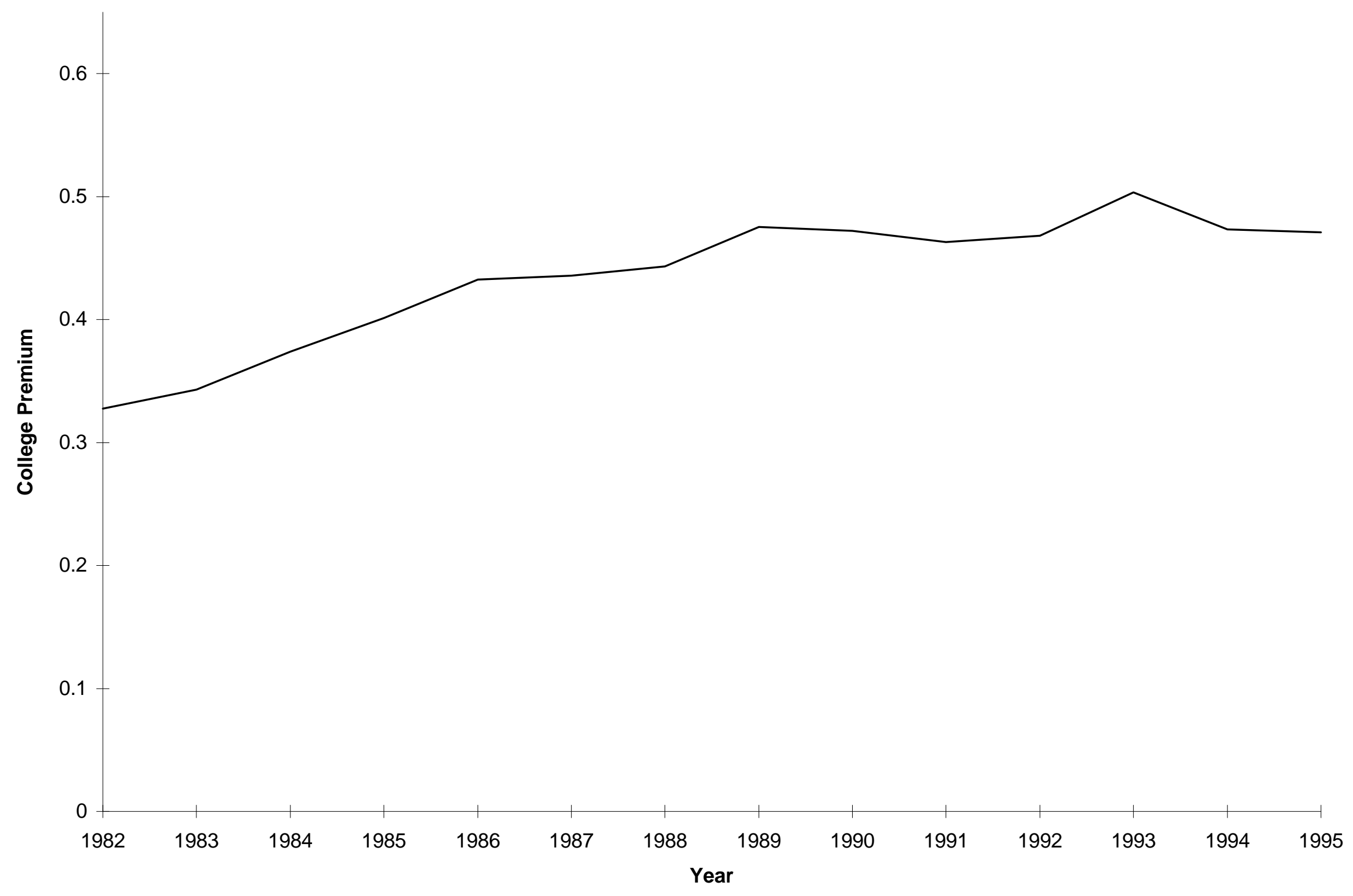

Source: Coefficient on college education in log earnings regression, estimated separately in each year from the March CPS.

Sample consists of individuals with 10 years or less of experience and 12 to 17 years of education. 
Table 1

Occupational College Premium, Percent of College Graduates, and Average Weekly Wages

1983 and 1994 -- March CPS

\begin{tabular}{|c|c|c|c|c|c|c|}
\hline $\begin{array}{c}{[1]} \\
\text { College } \\
\text { Premium } \\
1983\end{array}$ & $\begin{array}{c}{[2]} \\
\text { Percent of } \\
\text { College Graduates } \\
1983\end{array}$ & $\begin{array}{c}{[3]} \\
\text { Average } \\
\text { Weekly Wages } \\
1983\end{array}$ & $\begin{array}{c}{[4]} \\
\text { College } \\
\text { Premium } \\
1994\end{array}$ & $\begin{array}{c}{[5]} \\
\text { Percent of } \\
\text { College Graduates } \\
1994\end{array}$ & $\begin{array}{c}{[6]} \\
\text { Average } \\
\text { Weekly Wages } \\
1994\end{array}$ & Description \\
\hline-0.082 & 0.4 & $\$ 442$ & 0.643 & 0.3 & $\$ 370$ & Farm Occupations* \\
\hline-0.016 & 0.5 & $\$ 590$ & 0.247 & 0.5 & $\$ 417$ & Carpenters, Electricians, and Painters ${ }^{*}$ \\
\hline 0.018 & 4.0 & $\$ 510$ & 0.124 & 3.0 & $\$ 614$ & Registered Nurses \\
\hline 0.029 & 0.8 & $\$ 240$ & 0.101 & 0.8 & $\$ 293$ & Cashiers \\
\hline 0.056 & 0.4 & $\$ 254$ & 0.278 & 0.7 & $\$ 245$ & Cooks $^{\star}$ \\
\hline 0.061 & 0.5 & $\$ 355$ & 0.192 & 0.6 & $\$ 290$ & General Office Clerks \\
\hline 0.065 & 0.7 & $\$ 405$ & 0.157 & 0.4 & $\$ 624$ & Technicians, n.e.c. ${ }^{*}$ \\
\hline 0.078 & 1.8 & $\$ 338$ & 0.101 & 1.4 & $\$ 388$ & Financial Records Processing Occupations* \\
\hline 0.088 & 0.6 & $\$ 525$ & 0.146 & 0.5 & $\$ 533$ & Engineering Technicians, n.e.c. ${ }^{*}$ \\
\hline 0.095 & 0.5 & $\$ 518$ & 0.161 & 0.7 & $\$ 444$ & Fabricators and Assemblers, Miscellaneous Production Occupations ${ }^{*}$ \\
\hline 0.096 & 0.5 & $\$ 434$ & 0.294 & 0.5 & $\$ 642$ & Painters, Sculptors, and Photographers ${ }^{\star}$ \\
\hline 0.102 & 0.6 & $\$ 314$ & 0.175 & 0.5 & $\$ 405$ & Stenographers and Typists* \\
\hline 0.117 & 1.3 & $\$ 784$ & 0.437 & 1.6 & $\$ 856$ & Electrical and Electronic Engineers \\
\hline 0.121 & 0.4 & $\$ 545$ & 0.164 & 1.0 & $\$ 516$ & Legal Assistants \\
\hline 0.124 & 0.4 & $\$ 296$ & -0.046 & 0.2 & $\$ 238$ & Dental Assistants and Health Aides* \\
\hline 0.125 & 2.0 & $\$ 355$ & 0.190 & 2.4 & $\$ 326$ & Administrative Support Occupations, n.e.c. ${ }^{*}$ \\
\hline 0.130 & 0.8 & $\$ 525$ & 0.012 & 0.9 & $\$ 422$ & Transportation and Material Moving Occupations ${ }^{*}$ \\
\hline 0.136 & 0.9 & $\$ 192$ & 0.142 & 1.0 & $\$ 221$ & Waiters and Waitresses \\
\hline 0.137 & 0.9 & $\$ 299$ & 0.199 & 0.8 & $\$ 362$ & Records Processing Occupations, Except Financial ${ }^{\star}$ \\
\hline 0.151 & 0.5 & $\$ 842$ & 0.560 & 1.1 & $\$ 841$ & Securities and Financial Services Sales Occupations \\
\hline 0.152 & 0.5 & $\$ 566$ & 0.043 & 0.3 & $\$ 339$ & Drafting Occupations, Surveying and Mapping Technicians* \\
\hline 0.159 & 0.7 & $\$ 264$ & 0.322 & 0.8 & $\$ 292$ & Food Preparation and Service Occupations, Excluding Waiters and Waitresses* \\
\hline 0.168 & 0.3 & $\$ 497$ & 0.363 & 0.4 & $\$ 601$ & Mechanics and Repairers, Vehicle and Industrial Machinery* \\
\hline 0.169 & 2.2 & $\$ 365$ & 0.136 & 1.4 & $\$ 407$ & Secretaries \\
\hline 0.174 & 0.6 & $\$ 438$ & 0.297 & 1.0 & $\$ 425$ & Miscellaneous Adjusters and Investigators \\
\hline 0.174 & 0.4 & $\$ 294$ & 0.362 & 0.4 & $\$ 367$ & Nursing Aides \\
\hline 0.181 & 0.5 & $\$ 389$ & 0.358 & 0.5 & $\$ 536$ & Protective Service Occupations, Excluding Police and Detectives* \\
\hline 0.184 & 0.9 & $\$ 380$ & 0.192 & 1.2 & $\$ 316$ & Information Clerks ${ }^{\star}$ \\
\hline 0.185 & 0.8 & $\$ 454$ & 0.075 & 0.8 & $\$ 470$ & Machine Operators ${ }^{*}$ \\
\hline 0.187 & 0.5 & $\$ 372$ & 0.183 & 0.3 & $\$ 367$ & Agricultural, Forestry, Fishing, and Hunting Occupations* \\
\hline 0.201 & 0.4 & $\$ 444$ & 0.137 & 0.4 & $\$ 543$ & Computer Equipment Operators ${ }^{\star}$ \\
\hline 0.205 & 0.8 & $\$ 586$ & 0.270 & 1.0 & $\$ 694$ & Police and Detectives ${ }^{*}$ \\
\hline 0.208 & 0.4 & $\$ 562$ & 0.239 & 0.8 & $\$ 525$ & Insurance Adjusters, Examiners, and Investigators \\
\hline 0.212 & 0.5 & $\$ 489$ & 0.092 & 0.3 & $\$ 458$ & Mail and Message Distributing Occupations* \\
\hline 0.212 & 0.6 & $\$ 465$ & 0.251 & 0.4 & $\$ 421$ & Cleaning and Building Service Occupations, Excluding Household* \\
\hline 0.217 & 1.0 & $\$ 313$ & 0.291 & 0.6 & $\$ 295$ & Service Occupations, n.e.c.* \\
\hline 0.219 & 0.9 & $\$ 541$ & 0.519 & 0.8 & $\$ 569$ & Designers \\
\hline 0.220 & 2.3 & $\$ 344$ & 0.285 & 1.9 & $\$ 404$ & Sales Workers, Retail* \\
\hline 0.220 & 0.6 & $\$ 625$ & -0.108 & 0.3 & $\$ 325$ & Construction Trades, n.e.c. ${ }^{*}$ \\
\hline 0.226 & 0.7 & $\$ 367$ & 0.094 & 0.8 & $\$ 375$ & Handlers and Laborers, n.e.c. ${ }^{\star}$ \\
\hline 0.227 & 0.7 & $\$ 681$ & 0.212 & 0.3 & $\$ 547$ & Extractive and Precision Production Occupations ${ }^{*}$ \\
\hline 0.229 & 1.2 & $\$ 426$ & 0.256 & 1.2 & $\$ 419$ & Material Recording, Scheduling, and Distributing Clerks, n.e.c. ${ }^{\star}$ \\
\hline 0.235 & 0.5 & $\$ 488$ & 0.270 & 0.5 & $\$ 537$ & Other Mechanics and Repairers ${ }^{\star}$ \\
\hline 0.245 & 0.9 & $\$ 504$ & 0.508 & 0.8 & $\$ 623$ & Writers, artists, and related workers, n.e.c. ${ }^{*}$ \\
\hline 0.250 & 3.1 & $\$ 649$ & 0.434 & 4.3 & $\$ 611$ & Supervisors and Proprietors, Sales Occupations \\
\hline 0.255 & 0.4 & $\$ 568$ & 0.122 & 0.4 & $\$ 442$ & Science Technicians ${ }^{*}$ \\
\hline 0.256 & 4.5 & $\$ 617$ & 0.453 & 4.5 & $\$ 669$ & Accountants and Auditors \\
\hline 0.259 & 1.7 & $\$ 699$ & 0.255 & 1.6 & $\$ 680$ & Computer Programmers \\
\hline 0.261 & 0.8 & $\$ 536$ & 0.425 & 1.1 & $\$ 736$ & Therapists, n.e.c.* ${ }^{*}$ \\
\hline 0.263 & 1.6 & $\$ 615$ & 0.321 & 1.8 & $\$ 596$ & Miscellaneous Professional Specialty Occupations* \\
\hline 0.270 & 0.9 & $\$ 476$ & 0.432 & 0.6 & $\$ 541$ & Clinical Laboratory Technicians \\
\hline 0.277 & 1.3 & $\$ 490$ & 0.157 & 1.1 & $\$ 506$ & Editors and Reporters \\
\hline 0.278 & 1.1 & $\$ 546$ & 0.321 & 1.8 & $\$ 632$ & Miscellaneous Management Related Occupations ${ }^{\star}$ \\
\hline 0.279 & 0.4 & $\$ 306$ & 0.277 & 0.4 & $\$ 391$ & Freight, Stock, and Material Handlers ${ }^{\star}$ \\
\hline 0.286 & 0.7 & $\$ 567$ & 0.249 & 0.6 & $\$ 686$ & Insurance Sales Occupations \\
\hline 0.287 & 0.6 & $\$ 606$ & 0.292 & 0.5 & $\$ 548$ & Public Administration* ${ }^{*}$ \\
\hline 0.290 & 1.7 & $\$ 777$ & 0.368 & 3.2 & $\$ 786$ & Mathematical and Computer Scientists* \\
\hline 0.291 & 0.9 & $\$ 469$ & 0.339 & 0.9 & $\$ 636$ & Health Technicians, n.e.c. ${ }^{*}$ \\
\hline 0.294 & 0.6 & $\$ 723$ & 0.446 & 0.5 & $\$ 594$ & Supervisors, Production Occupations \\
\hline 0.297 & 0.5 & $\$ 441$ & 0.418 & 0.3 & $\$ 526$ & Sales Related Occupations ${ }^{*}$ \\
\hline 0.304 & 0.8 & $\$ 624$ & 0.546 & 0.5 & $\$ 682$ & Purchasing Agents and Buyers* \\
\hline 0.310 & 1.2 & $\$ 570$ & 0.438 & 2.1 & $\$ 698$ & Sales Occupations, Advertising and Other Business Services ${ }^{*}$ \\
\hline 0.312 & 7.3 & $\$ 683$ & 0.452 & 8.8 & $\$ 673$ & Miscellaneous Managers and Administrators* \\
\hline 0.321 & 0.9 & $\$ 696$ & 0.416 & 1.3 & $\$ 830$ & Financial Managers \\
\hline 0.323 & 1.7 & $\$ 427$ & 0.470 & 1.7 & $\$ 415$ & Social Workers \\
\hline 0.323 & 0.5 & $\$ 182$ & 0.276 & 0.6 & $\$ 275$ & Child Care Workers* \\
\hline 0.325 & 1.0 & $\$ 290$ & 0.400 & 1.0 & $\$ 349$ & Prekindergarten and Kindergarten Teachers \\
\hline 0.329 & 3.9 & $\$ 843$ & 0.394 & 2.7 & $\$ 803$ & Engineers, Not Elsewhere Classified ${ }^{*}$ \\
\hline 0.346 & 0.8 & $\$ 564$ & 0.426 & 0.8 & $\$ 622$ & Personnel, Training, and Labor Relations Specialists \\
\hline 0.354 & 1.3 & $\$ 597$ & 0.353 & 1.7 & $\$ 698$ & Miscellaneous Financial Officers \\
\hline 0.356 & 0.7 & $\$ 400$ & 0.633 & 0.7 & $\$ 390$ & Recreation and Religious Workers* \\
\hline 0.363 & 0.6 & $\$ 668$ & 0.233 & 0.6 & $\$ 693$ & Supervisors, Administrative Support Occupations* \\
\hline 0.364 & 2.5 & $\$ 689$ & 0.472 & 2.4 & $\$ 829$ & Sales Representatives, Commodities Except Retail ${ }^{*}$ \\
\hline 0.378 & 0.9 & $\$ 342$ & 0.206 & 0.9 & $\$ 391$ & Teachers, Not Elsewhere Classified \\
\hline 0.385 & 0.4 & $\$ 606$ & 0.382 & 0.4 & $\$ 613$ & Real Estate Sales Occupations \\
\hline 0.392 & 0.9 & $\$ 656$ & 0.290 & 0.7 & $\$ 405$ & Public Relations Specialists, Announcers, and Athletes* \\
\hline 0.409 & 0.6 & $\$ 760$ & 0.297 & 1.6 & $\$ 875$ & Managers, Marketing and Advertising \\
\hline 0.438 & 0.7 & $\$ 416$ & 0.348 & 0.5 & $\$ 412$ & Counselors, Librarians, Archivists, and Curators ${ }^{*}$ \\
\hline 0.471 & 0.5 & $\$ 760$ & 0.587 & 0.5 & $\$ 777$ & Real Estate Managers \\
\hline 0.536 & 1.1 & $\$ 687$ & 0.310 & 0.7 & $\$ 730$ & Health Assessment and Treating Occupations, n.e.c. ${ }^{*}$ \\
\hline 0.722 & 1.3 & $\$ 314$ & 0.724 & 1.1 & $\$ 282$ & Postsecondary Teachers ${ }^{\star}$ \\
\hline
\end{tabular}


Figure 2

Young College Graduates By Occupational College Premium - 1983 and 1994 Kernel Density Estimates - March CPS

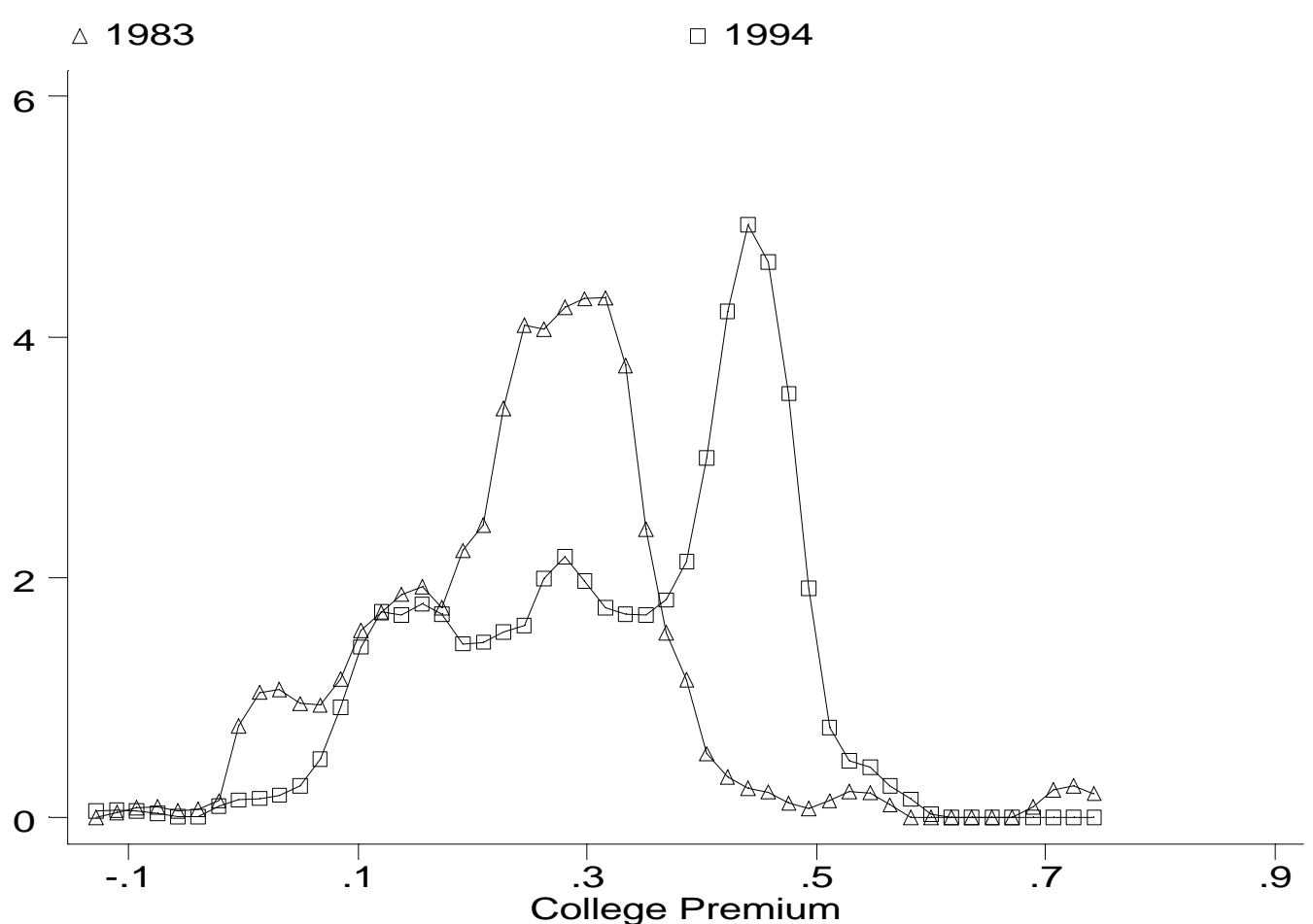

Source: Authors' tabulation of the March CPS. 
Table 2

Logit Estimates of Probability

That A Young College Graduate Is

Employed in a Non-College Job

1983-1994 -- March CPS

(Year - 1983)

Female

Black

Hispanic

Unemployment

Rate

Constant

$-3.017$
[1]

Coefficient

[2]

Marginal Effects

$-0.006$

0.005

$(0.003)^{*}$

0.669

0.034

$(0.042)^{\star \star \star}$

$-0.270$

$-0.014$

$(0.220)$

$-0.229$

$-0.012$

$(0.215)$

0.064

$(0.028)^{\star *}$

0.003

$(0.214)^{\star \star *}$

Sample consists of college graduates with 10 years or less potential experience.

Standard errors are in parentheses.

Asterisks indicate significance at the ${ }^{*} 10 \%,{ }^{* *} 5 \%$, and ${ }^{* * *} 1 \%$ levels.

Marginal effects are measured using the average derivative. 
Figure 3

Probability That A Young College Graduate

Is Employed In A Non-College Occupation

1983-1994 -- March CPS

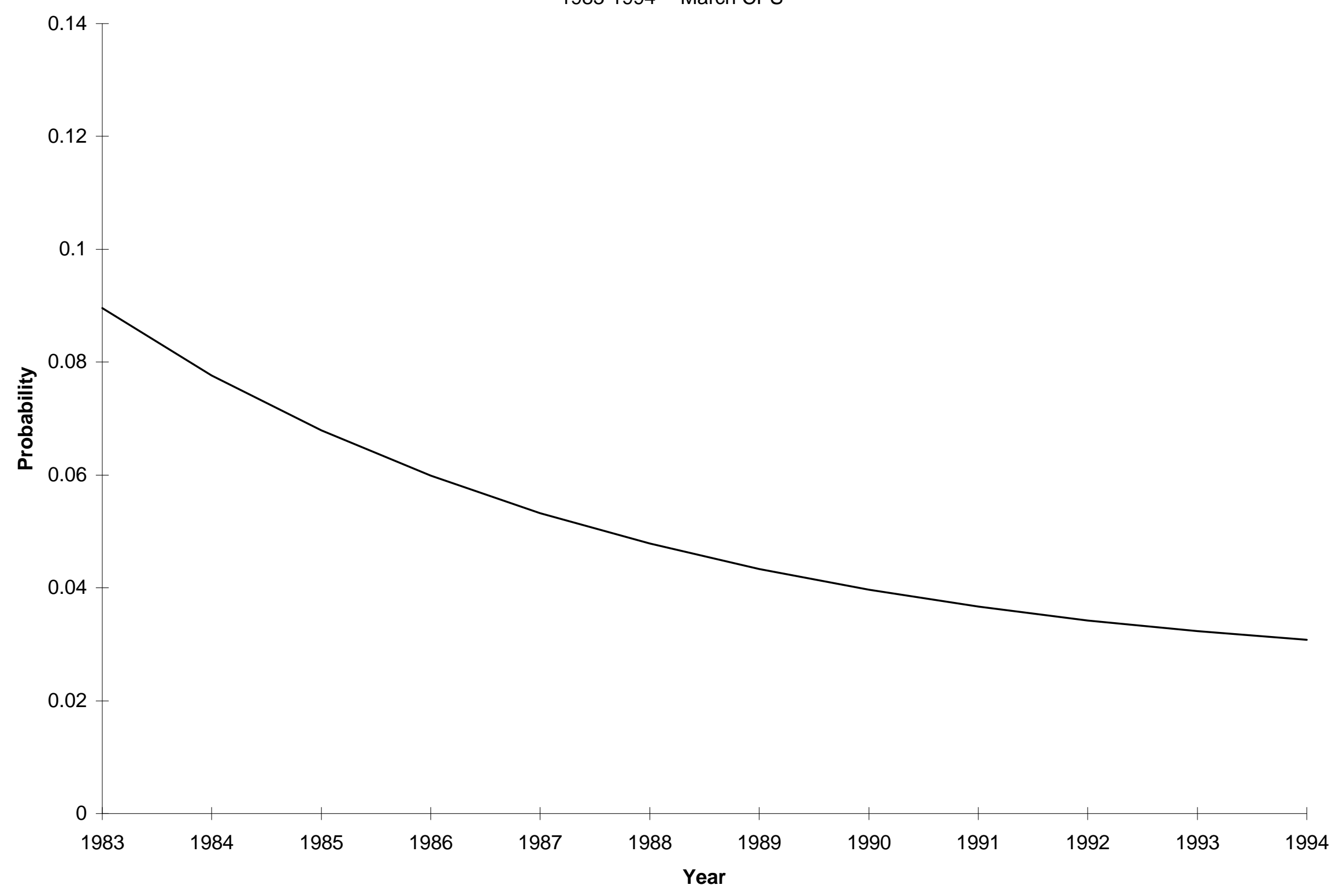

Source: Predicted values from logit estimation (Table 2), evaluated at sample means.

Occupations are considered non-college jobs if the estimated college premium is $<=.10$. 
Table 3

Logit Estimates of Probability

That A Young College Graduate Is

Employed in a Non-College Job

Hecker Approach

1983-1994 -- March CPS

(Year - 1983)

$($ Year - 1983)^2

Female

Black

Hispanic

Unemployment

Rate

Constant
[1]

Coefficient

0.011

(0.015)

0.002

[2]

Marginal Effects

0.000

(0.003)

0.182

$(0.020)^{\star * \star}$

0.216

$(0.094)^{\star *}$

0.130

(0.094)

0.041

$(0.013)^{* * *}$

$-1.433$

$(0.097)^{\star \star \star}$
0.042

0.025

0.035

0.008

Sample consists of college graduates with 10 years or less potential experience.

Standard errors are in parentheses.

Asterisks indicate significance at the ${ }^{*} 10 \%,{ }^{*} 5 \%$, and ${ }^{* * *} 1 \%$ levels.

Marginal effects are measured using the average derivative. 